\title{
Atypical presentation of Charcot-Marie-Tooth disease type $2 Q$ by mutations on DHTKD1 and NTRK2 genes
}

\author{
Dulce M. Castro-Coyotl ${ }^{1}$, Israel E. Crisanto-López ${ }^{2 *}$, Rosa M. Hernández-Camacho ${ }^{3}$, and \\ María P. Saldaña-Guerrero² \\ ${ }^{1}$ Centro de Rehabilitación e Inclusión Infantil Teletón; ${ }^{2}$ Departamento de Genética, Facultad de Medicina, Benemérita Universidad Autónoma de \\ Puebla; ${ }^{3}$ Departamento de Genética del Instituto Mexicano del Seguro Social. Puebla, Puebla, Mexico
}

\begin{abstract}
Background: Charcot-Marie-Tooth disease type $2 Q(C M T 2 Q)$ is a rare disorder $(<1 / 1,000,000$ individuals worldwide) linked to chromosome 10p14 in the DHTKD1 gene. This phenotype is characterized by an adolescent or adulthood-onset, slowly progressive distal muscle weakness and symmetrical atrophy associated with reduced or absent deep tendon reflexes. Currently, only two familiar cases from China have been reported: one familiar case of eight individuals affected by isolated DHTKD1 gene mutation and one familiar case of two individuals affected by DHTKD1 gene mutation and GJB1 gene mutation. Case report: We present the case of a 10-year-old male patient with obesity, frequent falls, swollen legs and thighs, and pain in the lower and upper limbs. We performed the clinical evaluation and a clinical targeted exome test, which reported mutations on DHTKD1 y NTRK2 genes. Conclusions: Due to scientific and technological advances, genetic dysfunctions that can cause different diseases have been identified with greater sensitivity. Globally, this is the eleventh case reported of DHTKD1 gene mutation linked to CMT2Q. Moreover, this is the first case related to NTRK2 gene mutation (linked to obesity, hyperphagia, and delayed development). The patient showed an atypical CMT2Q phenotype additional to obesity. Therefore, we propose to study metabolic disorders linked to hereditary peripheral neuropathies.
\end{abstract}

Keywords: Charcot-Marie-Tooth disease. Hereditary motor and sensory neuropathy. DHTKD1. NTRK2.

\section{Presentación atípica de enfermedad de Charcot-Marie-Tooth tipo $2 Q$ por mutaciones en los genes DHTKD1 y NTRK2}

\section{Resumen}

Introducción: La enfermedad de Charcot-Marie-Tooth tipo 2Q (CMT2Q) es una alteración poco frecuente $(<1 / 1,000,000$ habitantes en todo el mundo) condicionada por mutaciones en el gen DHTKD1, localizado en el cromosoma 10p14. El padecimiento inicia en la adolescencia o la edad adulta de manera lenta y progresiva, con debilidad muscular y atrofia distal simétrica, $y$ afecta predominantemente las extremidades inferiores y los reflejos tendinosos profundos, que se encuentran reducidos o ausentes. Solo se ha reportado un caso familiar de ocho personas afectadas con la mutación aislada en el gen

Correspondence:

*Israel E. Crisanto-López

E-mail: israel.crisanto@alumno.buap.mx
Available online: 17-09-2021

Date of reception: 02-02-2021 Date of acceptance: 12-04-2021 DOI: 10.24875/BMHIM.21000016
Bol Med Hosp Infant Mex. 2021;78(5):474-478

www.bmhim.com 1665-1146/@ 2021 Hospital Infantil de México Federico Gómez. Published by Permanyer. This is an open access article under the CC BY-NC-ND license (http://creativecommons.org/licenses/by-nc-nd/4.0/). 
DHTKD1 y un caso familiar de dos personas afectadas con mutaciones en los genes DHTKD1 y GJB1, ambas familias de China. Caso clínico: Se presenta el caso de un paciente de sexo masculino de 10 años y 11 meses de edad con obesidad, caídas frecuentes, edema de miembros pélvicos y dolor en las extremidades inferiores y superiores. Se realizaron valoración clínica y estudio genético molecular de exoma dirigido, el cual reportó mutaciones en los genes DHTKD1 y NTRK2. Conclusiones: Gracias al avance científico y tecnológico se han podido identificar con mayor precisión las alteraciones genéticas causantes de diferentes enfermedades. Este es el undécimo caso reportado en el mundo de una mutación en el gen DHTKD1 asociada con la enfermedad de CMT2Q. También es el primer caso relacionado con una mutación del gen NTRK2 (asociada con obesidad, hiperfagia y retraso en el desarrollo). El paciente presentó un cuadro clínico atípico de enfermedad de CMT2Q agregado a obesidad. Por ello, se sugiere estudiar a fondo la conexión entre trastornos metabólicos y neuropatías periféricas hereditarias.

Palabras clave: Enfermedad de Charcot-Marie-Tooth. Neuropatía hereditaria sensitivomotora. DHTKD1. NTRK2.

\section{Introduction}

Charcot-Marie-Tooth disease, also known as hereditary sensorimotor neuropathy, describes a large heterogeneous group of hereditary neuropathies ${ }^{1,2}$ representing the most common hereditary neuromuscular disease, with a prevalence of 1/2500 individuals worldwide ${ }^{3,4}$. Clinically, it affects the distal extremities, presenting progressive muscular and sensory defects, atrophy, and chronic weakness ${ }^{5}$. The inheritance pattern can be autosomal dominant (AD), autosomal recessive (AR), or X-linked. According to the motor conduction velocity (MCV) of the median nerve, these neuropathies are classified as demyelinating (MCV $<38 \mathrm{~m} / \mathrm{s}$ ), axonal (MCV > $38 \mathrm{~m} / \mathrm{s}$ ), and intermediate (MCV $30-40 \mathrm{~m} / \mathrm{s})^{6-8}$.

Dyck proposed to consider the neurophysiological and pathological findings to classify these conditions as type I (CMT1, hypertrophic or demyelinating) with AD or AR inheritance; type II (CMT2, neuronal or axonal) with AD or AR inheritance; type III (CMT3, with AR inheritance) reserved for Dejerine-Sottas disease or patients with severe forms of hypomyelinating CMT; X-linked complex forms, with optic atrophy, deafness, or retinal pigmentary degeneration ${ }^{9}$. Currently, etiopathological mechanisms have been established thanks to scientific and technological progress ${ }^{10}$, and the corresponding genetic alterations have been pinpointed, generating more specific genotypes of the disease ${ }^{11}$.

One of these genotypes is Charcot-Marie-Tooth disease type $2 \mathrm{Q}$ (CMT2Q) of $A D$ inheritance. It is a rare phenotype $(<1 / 1,000,000$ inhabitants worldwide), characterized by adolescence or adulthood onset. The patients present slowly and progressively muscle weakness and symmetric distal atrophy, predominantly in the lower extremities; other signs are pes cavus and mild to moderate deep sensory disturbances ${ }^{12}$. This disease is caused by a heterozygous mutation of the nuclear DHTKD1 (Dehydrogenase E1 and Transketolase Domain Containing 1) gene encoding the mitochondrial DHTKD1 protein $^{13}$.

Recent studies have shown that the DHTKD1 gene produces the hE1 protein, which is part of the 2-ketoadipic acid complex, involved in the catabolism of lysine and tryptophan ${ }^{14-16}$, both directly related to the Krebs cycle and ATP production ${ }^{17,18}$. Mutations of this gene induced in experimental models produce blockage of metabolic pathways and 2-aminoadipic and 2-oxoadipic aciduria (AMOXAD) $)^{14,19}$.

In the literature, only eight patients (five males and three females) in a family from Shandong province, China, have been reported with the c.1455T>G (p.Tyr485) mutation in exon 8 of the DHTKD1 gene (in isolation) ${ }^{17}$. Furthermore, in 2019, Zhao et al. reported two more cases from another family in China with two mutations in CMT disease-related genes: the $c .2369 \mathrm{C}>T$ mutation in the DHTKD1 gene and the mutation in c.258_530 of the AGT of the GJB1 (Gap Junction Beta 1) gene, which is a significant cause of $X$-linked CMT type 1 disease 20,21 .

For genetic diseases study protocols, specific techniques are used to determine alterations at the genomic level. One of them is the targeted exome test, which consists of the design of genetic panels based on the patient's clinical history, in which a massive sequencing of more than 200,000 exons $(99.68 \%$ of the coding human genome) is performed on a sample of the patient's DNA. Subsequently, with a bioinformatics algorithm, the identified variants are prioritized based on their pathogenic potential. If they are not reported, in silico prediction of the variants is performed. If a diagnosis cannot be concluded, other genes can be included, or the entire exome can be analyzed.

The objective of this report was to present the eleventh case of a mutation in the DHTKD1 gene 
(associated with CMT2Q) and the first case related to a mutation in the NTRK2 gene (associated with obesity, hyperphagia, and developmental delay).

\section{Clinical case}

We present the case of a 10-year-and-11-month old male product of second pregnancy of non-consanguineous healthy parents (31-year-old mother, 33-year-old father) and a healthy 13-year-old sister, with no genetic history of any pathology similar to that of the patient. Adequate prenatal control started in the first trimester with a total of 10 consultations. With a normal pregnancy evolution, delivery was performed at 39 weeks via cesarean section due to placenta previa. The child cried and breathed at birth, and a weight of 3,100 grams and height of $51 \mathrm{~cm}$ were recorded; Apgar 10 at $5 \mathrm{~min}$ utes, without perinatal complications. Psychomotor development reported head support at 3 months, sitting at 6 months, standing at 10 months, walking at 16 months, beginning of monosyllables production at 22 months, complete sentences at 2.5 years, teething at 6 months, and sphincter control at 2 years.

At 10 years and 9 months, the patient began with muscle weakness and edema of the lower limbs, frequent falls, pain in upper and lower extremities, abdominal pain, diarrhea on average twice a week, sleep disturbances, and significant weight loss (approximately $20 \mathrm{~kg}$ in four months), for which the parents decided to seek medical attention.

The physical examination revealed a weight of $65 \mathrm{~kg}$ ( $Z$ score $>3$, obesity), a height of $1.68 \mathrm{~m}$ ( $Z$ score $>3$, very high), body mass index of 23 ( $Z$ score $>2$, obesity). Also, normocephalus, cranial nerves examination without alterations, preserved cognitive functions, dislocated shoulders with full ranges of motion, slightly clawed hands, the strength of the four extremities was $5 / 5$ in proximal and medial areas and $4 / 5$ distally according to the Daniels scale, preserved sensitivity (proprioceptive and exteroceptive), positive muscle stretch reflex ++ , gait without alterations, and normal psychomotor development.

The rehabilitation physician requested electromyography and specific laboratory studies; later, the patient was referred to the Genetics service for probable mitochondrial disease. Laboratory studies reported blood chemistry, aldolase, glutamic oxaloacetic transaminase, alanine aminotransferase, lactate dehydrogenase, and rheumatoid factor results within normal ranges. Biological markers results were as follows: creatine phosphokinase (CPK), $197 \mathrm{U} / \mathrm{L}$ (in normal parameter); CPK-MB, $25 \mathrm{ng} / \mathrm{mL}$ (high); lactate, 2.7 $\mathrm{mmol} / \mathrm{L}$ (high). After observing elevated CPK-MB levels in a pediatric patient, the diagnosis was oriented towards a muscle-type alteration, such as dystrophy or myopathy, coupled with elevated lactate, which refers to an anaerobic pathway in adenosine triphosphate (ATP) synthesis. Radiology studies (chest X-ray, head magnetic resonance imaging, liver and bile duct ultrasound, and electrocardiogram) were reported without alterations. Electromyography and nerve conduction velocity concluded motor polyneuropathy with axonal degeneration. The myography study reported a mixed neuropathic and myopathic pattern.

Upon evaluation of the patient by a geneticist and according to the age group with symptoms of decreased muscle strength, significant weight loss, alteration of biological muscle markers, electromyography tests, and nerve conduction velocity, suspicion of mitochondrial neurogastrointestinal encephalomyopathy was concluded. We carried out an exome study for mitochondrial diseases; as a mitochondrial pathology was not detected, the search was extended to peripheral neuropathies. The directed exome genetic study reported two variants of uncertain clinical significance in a heterozygous state located in the DHTKD1 gene [OMIM: 614984], associated with Charcot-Marie-Tooth disease type $2 \mathrm{Q}$ and NTRK2 [OMIM: 600456] associated with obesity, hyperphagia, and developmental delay. These variants were identified based on the GRCh38 reference genomic sequence and in silico prediction programs, using various databases to classify them according to their possible pathogenic potential.

\section{Discussion}

Only eight cases have been reported worldwide of CMT2Q disease attributed to the c.1455T>G (p.Tyr485) mutation of the DHTKD1 gene [OMIM: 614984]. The present case is relevant due to the identification of two mutations. The first mutation, c.2090T>G, is a heterozygous transversion of a thymine residue by guanine at position 2090 of the coding region of the DHTKD1 gene (exon 12 of 17), which generates a nonsynonymous change of a leucine residue by an arginine residue at position 697 of the encoded protein sequence. The second mutation, c.64C>A in the same gene, is another heterozygous transversion of a cytosine residue by an adenine at position 64 of the coding region of the DHTKD1 gene (exon 1 of 17), which generates a nonsynonymous change of an arginine residue by 
serine at position 22 of the encoded protein sequence. Based on the American College of Medical Genetics and Genomics guidelines, both mutations have been classified as of uncertain clinical significance. Although they rarely occur individually, in silico analysis predicts them to be deleterious, and c.2090T>G is located in a functional domain of the encoded protein.

These results suggest the development of early-onset CMT2Q disease, which is consistent with motor axonal polyneuropathy in this patient.

Currently, the role of the DHTKD1 gene is still under study. It was demonstrated that it contributes to ATP production by degrading L-lysine, L-hydroxylysine, and L-tryptophan in the mitochondria within the Krebs cycle and reducing reactive oxygen species such as $\mathrm{H}_{2} \mathrm{O}_{2}^{22-24}$. In addition, it has been associated with conditions such as CMT2Q, AMOXAD, metabolic disorders, neurological abnormalities, and eosinophilic esophagitis ${ }^{25,26}$.

The pathophysiology related to the mutation in DHTKD1 is not yet clear, but it is proposed that the levels of 2-ketoadipic acid (2-KAA) and 2-aminoadipic acid (2-AAA) increase. These high levels stimulate the biosynthesis and release of insulin, and subsequently the abnormal transcription of myelin protein zero (MPZ) in Schwann cells via early growth response 2 (Egr2), thus generating damage to the myelin structure and axonal degeneration. In other words, altered function of the DHTKD1 gene causes CMT2Q by dysregulation of MPZ mRNA expression ${ }^{18}$.

Together, alterations in the DHTKD1 gene generate a decrease in ATP production, limiting the energy available for cellular functions. They also alter the biosynthesis and maintenance of mitochondria, unbalancing intracytoplasmic oxidizing agents and antioxidants, and increase the release of amino acid metabolites such as 2-KAA and 2-AAA, affecting MPZ mRNA expression.

Moreover, another c. $2378 \mathrm{C}>\mathrm{G}$ mutation was identified in the NTRK2 gene: a heterozygous transversion of a cytosine residue by guanine at position 2378 of the coding region of the NTRK2 gene (exon 19 of 19). This transversion generates a nonsynonymous change of a threonine residue to an arginine residue at position 793 of the encoded protein sequence. This variant was classified as being of uncertain clinical significance. Although it is localized within a functional domain of the encoded protein, it occurs at an extremely low frequency and is predicted to be deleterious in silico (PP3).

These alterations may account for the atypical presentation of the patient. Pathogenic variants located in the NTRK2 gene are associated with obesity, hyperphagia, and developmental delay [OMIM: 613886], as well as with early-onset childhood epileptic encephalopathy [OMIM: 617830] $]^{27,28}$.

This gene encodes a protein belonging to the neurotrophic tyrosine kinase receptor type II class IV family (TrkB), which is autophosphorylated in a ligand-dependent manner and phosphorylates proteins belonging to the mitogen-activated protein kinase (MAP kinase) pathway, leading to cell differentiation. TrkB protein is a receptor for neurotrophins such as brain-derived neurotrophic factor (BDNF), neurotrophin-3 (NT-3), and neurotrophin-4/5 (NT-4/5). Thus, it is involved in the development and maturation of the central and peripheral nervous system by regulating neuronal survival, proliferation, migration, differentiation, synapse formation, and plasticity (by similarity) ${ }^{27,29}$.

In conclusion, the mutation variants presented in this case have not been reported as potentially pathogenic in any public database. However, the patient's clinical presentation is consistent with the alterations of both genetic mutations reported in different studies. The present report contributes to the scientific evidence of the relationship between metabolic disorders and mitochondrial dysfunction as causes of peripheral neuropathies.

\section{Ethical disclosures}

Protection of human and animal subjects. The authors declare that no experiments were performed on humans or animals for this study.

Confidentiality of data. The authors declare that they have followed the protocols of their work center on the publication of patient data.

Right to privacy and informed consent. The authors have obtained the written informed consent of the patients or subjects mentioned in the article. The corresponding author has this document.

\section{Conflicts of interest}

The authors declare no conflicts of interest since the professional judgment was focused only on the patient's well-being.

\section{Conflicts of interest}

The authors declare no conflict of interest.

\section{Funding}

None. 


\section{References}

1. Lupski JR, de Oca-Luna RM, Slaugenhaupt S, Pentao L, Guzzetta V, Trask BJ, et al. DNA duplication associated with Charcot-Marie-Tooth disease type 1A. Cell. 1991;66:219-32.

2. Baets J, De Jonghe P, Timmerman V. Recent advances in Charcot-Marie-Tooth disease. Curr Opin Neurol. 2014;27:532-40.

3. Stojkovic T. Hereditary neuropathies: an update. Rev Neurol (Paris). 2016;172:775-8.

4. Lupski JR, Reid JG, Gonzaga-Jauregui C, Rio Deiros D, Chen DCY, Nazareth $L$, et al. Whole-genome sequencing in a patient with Charcot-Marie-Tooth neuropathy. N Engl J Med. 2010:362;1181-91.

5. Dyck PJ, Lambert EH. Lower motor and primary sensory neuron diseases with peroneal muscular atrophy. I. Neurologic, genetic, and electrophysiologic findings in hereditary polyneuropathies. Arch Neurol 1968;18:603-18.

6. Harding AE, Thomas PK. The clinical features of hereditary motor and sensory neuropathy types I and II. Brain. 1980;103:259-80

7. Shy ME, Lupski JR, Chance PH, Klein CJ, Dyck PJ. Hereditary Motor and Sensory Neuropathies. In: Dyck PJ, Thomas PK, editors. Peripheral neuropathy. Philadelphia: Elsevier Saunders; 2005. pp. 1623-58.

8. Pareyson D, Marchesi C. Diagnosis, natural history, and management of Charcot-Marie-Tooth disease. Lancet Neurol. 2009;8:654-67.

9. Dyck PJ. Inherited Neuronal Degeneration and Atrophy Affecting Peripheral Motor, Sensory, and Autonomic Neurons. In: Dyck PJ, Thomas PK, Lambert EH, editors. Peripheral neuropathy. Philadelphia: Elsevier Saunders; 1975. pp. 825-67.

10. Niemann A, Berger $P$, Suter U. Pathomechanisms of mutant proteins in Charcot-Marie-Tooth disease. Neuromolecular Med. 2006;8:217-42.

11. Berciano J, Sevilla T, Casasnovas C, Sivera R, Vílchez JJ, Infante J, et al. Guía diagnóstica en el paciente con enfermedad de Charcot-Marie-Tooth. Neurología. 2012;27:169-78.

12. www.orpha.net [Internet]. Paris: INSERM; 1999.

13. Protocole National de Diagnostic et de soins. [Neuropathies héréditaires sensitivomotrices de Charcot-Marie-Tooth]. PNDS. 2020:31. Available from: https://www. has-sante.fr/upload/docs/application/pdf/2020-03/pnds-cmt-sa-v2-converti.pdf

14. Xu WY, Zhu H, Shen Y, Wan YH, Tu XD, Wu WT, et al. DHTKD1 deficiency causes Charcot-Marie-Tooth disease in mice. Mol Cell Biol. 2018;38:e00085-18.

15. Danhauser K, Sauer SW, Haack TB, Wieland T, Staufner C, Graf E, et al. DHTKD1 mutations cause 2-aminoadipic and 2-oxoadipic aciduria. Am Hum Genet. 2012;91:1082-7.

16. Hagen $J$, te Brinke $H$, Wanders RJ, Knegt AC, Oussoren $E$, Hoogeboom AJ, et al. Genetic basis of alpha-aminoadipic and alpha-ketoadipic aciduria. J Inherit Metab Dis. 2015;38:873-9.
17. Xu WY, Gu MM, Sun LH, Guo W, Zhu H, Ma J, et al. A nonsense mutation in DHTKD1 causes Charcot-Marie-Tooth disease type 2 in a large Chinese pedigree. Am J Hum Genet. 2012;91:1088-94.

18. Xu W, Zhu H, Gu M, Luo Q, Ding J, Yao Y, et al. DHTKD1 is essential for mitochondrial biogenesis and function maintenance. FEBS Lett. 2013;587:3587-92.

19. Stiles AR, Venturoni L, Mucci G, Elbalalesy N, Woontner M, Goodman S, et al. New Cases of DHTKD1 mutations in patients with 2-ketoadipic aciduria. JIMD Rep. 2016;25:15-9.

20. Zhao ZH, Chen ZT, Zhou RL, Wang YZ. A Chinese pedigree with a novel mutation in GJB1 gene and a rare variation in DHTKD1 gene for diverse Charcot-Marie-Tooth diseases. Mol Med Rep. 2019;19:4484-90.

21. Yuan JH, Sakiyama Y, Hashiguchi A, Ando M, Okamoto Y, Yoshimura A, et al. Genetic and phenotypic profile of 112 patients with X-linked Charcot-Marie-Tooth disease type 1. Eur J Neurol. 2018;25:1454-61.

22. Jordan F, Nemeria N, Gerfen G. Human 2-oxoglutarate dehydrogenase and 2-oxoadipate dehydrogenase both generate superoxide $/ \mathrm{H}_{2} \mathrm{O}_{2}$ in a side reaction and each could contribute to oxidative stress in mitochondria. Neurochem Res. 2019;44:2325-35.

23. Bunik VI, Sievers C. Inactivation of the 2-oxo acid dehydrogenase complexes upon generation of intrinsic radical species. Eur J Biochem. 2002;269:5004-15.

24. Starkov AA, Fiskum G, Chinopoulos C, Lorenzo BJ, Browne SE, Patel MS, et al. Mitochondrial alpha-ketoglutarate dehydrogenase complex generates reactive oxygen species. J Neurosci. 2004;24:7779-88.

25. Nemeria NS, Gerfen G, Yang L, Zhang X, Jordan F. Evidence for functional and regulatory cross-talk between the tricarboxylic acid cycle 2-oxoglutarate dehydrogenase complex and 2-oxoadipate dehydrogenase on the I-lysine, I-hydroxylysine and I-tryptophan degradation pathways from studies in vitro. Biochim Biophys Acta Bioenerg. 2018;1859:932-9.

26. Nemeria NS, Gerfen G, Nareddy PR, Yang L, Zhang X, Szostak M, et al. The mitochondrial 2-oxoadipate and 2-oxoglutarate dehydrogenase complexes share their E2 and E3 components for their function and both generate reactive oxygen species. Free Radic Biol Med. 2018; 115:136-45.

27. Yeo GS, Connie Hung CC, Rochford J, Keogh J, Gray J, Sivaramakrishnan $S$, et al. A de novo mutation affecting human TrkB associated with severe obesity and developmental delay. Nat Neurosci. 2004;7:1187-9.

28. Hamdan FF, Myers CT, Cossette P, Lemay P, Spiegelman D, Laporte DA, et al. High rate of recurrent de novo mutations in developmental and epileptic encephalopathies. Am J Hum Genet. 2017;101:664-85.

29. Haniu M, Talvenheimo J, Le J, Katta V, Welcher A, Rohde MF. ExtraceIlular domain of neurotrophin receptor trkB: disulfide structure, N-glycosylation sites, and ligand binding. Arch Biochem Biophys. 1995;322:256-64. 